\title{
Strategi Pembentukan Sikap Disiplin Warga Negara Muda Melalui Persekolahan
}

\author{
Mariyani $^{1}$, Abdul Gafur ${ }^{2}$ \\ ${ }^{1,2}$ Program Studi PPKn Universitas Negeri Yogyakarta \\ 1mariyani573@gmail.com \\ 2abdul_gafur@uny.ac.id
}

\begin{abstract}
ABSTRAK
Pembentukan sikap disiplin menjadi wujud nyata aktualisasi karakter personal pada diri warga negara muda. Sikap disiplin harus dibentuk oleh berbagai pihak salah satunya ialah melalui persekolahan. Sikap disiplin penting untuk dibentuk pada warga negara muda dikarenakan beberapa hasil penelitian menunjukkan bahwa salah satu indikator untuk menggambarkan kualitas pendidikan suatu negara ialah tingkat disiplin warga negaranya. Selain itu rendahnya sikap disiplin merupakan salah satu penyebab seseorang melakukan hal-hal yang bertentangan dengan nilai-nilai yang harusnya dilaksanakan. Sikap disiplin merupakan sikap yang menunjukkan perilaku patuh dan taat terhadap peraturan yang ada secara sadar, tanpa ada paksaan, bersifat melekat dan menjadi kebiasaan. Tujuan tulisan ini ialah untuk mengetahui strategi pembentukan sikap disiplin warga negara muda melalui persekolahan. Metode yang digunakan dalam tulisan ini ialah kajian pustaka (library research). Tulisan ini akan membahas tentang 1) urgensi sikap disiplin; 2) strategi pembentukan sikap disiplin melalui pengembangan budaya sekolah dengan melakukan pembiasaan keteladanan, pembiasaan spontan, pembiasaan rutin dan pengkondisian; 3) strategi pembentukan sikap disiplin melalui pengelolaaan iklim kelas yang kondusif sehingga upaya membentuk sikap disiplin siswa akan lebih mudah jika guru dan siswa secara berkolaboratif membangung iklim kelas yang baik dan 3) strategi pembentukan sikap disiplin melalui program boarding school.
\end{abstract}

Kata kunci: Disiplin warga negara, persekolahan, strategi

\section{PENDAHULUAN}

Sikap disiplin merupakan salah satu aktualisasi nilai yang harus dibentuk di dalam diri warga negara muda. Hal ini dikarenakan warga negara yang baik secara personal haruslah mengembangkan nilai-nilai personal salah satunya disiplin. Pentingnya karakter disiplin juga di perkuat oleh hasil penelitian PERC bahwa untuk menggambarkan kualitas pendidikan suatu negara salah satu indikatornya ialah tingkat disiplin warga negara. Survei yang dilakukan oleh PERC di lansir melalui Tribun News Aceh bahwa Indonesia menunjukkan posisi kurang baik dalam sistem pendidikan dengan menempati posisi kurang baik yaitu ke- 111 dari 175 negara sampel yang ada. Salah satu indikator rendahnya kualitas pendidikan Indonesia ialah itingkat kedisiplinan warga negara yang rendah. Selain itu kurangnya sikap disiplin warga negara juga mengakibatkan banyak timbul perilaku-perilaku menyimpang dalam hal ini terkait dengan kenakalan remaja yang sekarang cenderung bertentangan dengan nilai-nilai Pancasila yang menjadi dasar berpedoman seseorang. Hal ini di perkuat oleh pendapat
Sjarkawi (2011: 44) bahwa kecenderungan berperilaku yang amoral atau bertentangan dengan nilai-nilai yang berlaku di dalam masyarakat diakibatkan kurangnya sikap disiplin pada diri seseorang. Secara lebih khusus permasalahan dalam dunia pendidikan juga ditunjukkan dengan masih banyak ditemukan kasus-kasus penyalah gunaan obat terlarang di persekolahan, tawuran antar pelajar, sistem geng hingga pada pelanggaran tata tertib sekolah. Komisi Nasional Perlindungan Anak dan Badan Narkotika Nasional (BNN) menunjukkan hasil survei bahwa remaja usia SMP dan SMA di Indonesia sebanyak $63 \%$ telah melakukan hubungan seks di luar nikah dan pengguna obat-obat terlarang dari pelajar dan mahasiswa sebanyak $22 \%$.

Hal ini jelas bahwa fenomena seperti uraian sebelumnya mengindikasikan pentingnya sikap disiplin sebagai karakter personal untuk diaktualisasikan dalam kehidupan nyata. Sikap disiplin yang dimaksud ialah sikap yang digambarkan melalui kepatuhan berperilaku tertib sesuai dengan ketentuan dan peratuan yang telah di sepakati bersama. Perilaku tersebut haruslah didasari 
oleh kesadaran diri seseorang sehingga mampu menjadi pembiasaan atau habituasi dalam berperilaku dalam kehidupan sehari-hari.

Upaya mencapai tujuan pembentukan sikap disiplin warga negara muda tersebut haruslah dilaksanakan secara integratif antar berbagai komponen. Komponen yang dimaksud dalam hal ini dibentuk berdasarkan oleh dua faktor yang meliputi 1) faktor internal (kesadaran, motivasi dan kemauan) dan 2) faktor eksternal (keluarga, sekolah dan masyarakat) yang setiap faktor tersebut memberikan sumbangsih yang berbeda akan tetapi berkaitan satu sama lain untuk membentuk sikap disiplin warga negara (Maksudin, 2013: 45-50). Setiap komponen terintegrasi secara utuh akan tetapi dalam tulisan ini faktor yang menjadi fokus ialah faktor eksternal melalui persekolahan. Salah satu alasan bahwa sekolah memberikan kontribusi besar dalam pembentukan sikap disiplin dikarenakan sekolah memiliki program yang lebih terencana dan terprogram lebih efektif dan efisien.

Faktor persekolahan lebih efektif dalam memberikan kontribusi dalam pembentukan karakter seseorang. Hal ini dikemukakan oleh Fathurahman (2012: 18131816) bahwa aspek pendukung terwujudnya pendidikan karakter dalam hal ini sikap disiplin ialah a) modeling; b) sistem pendidikan yang bebas dan menyenangkan; c) sistem boarding school; d) model pembelajaran kooperatif; e) guru yang cerdas, humanis dan religius serta f) komunikasi. Oleh karena itu peran persekolahan dalam pembentukan sikap disiplin haruslah diaktualisakasikan secara lebih efektif dengan mengembangkan semua komponen yang ada di sekolah dengan keterlibatan setiap warga sekolah mulai dari budaya sekolah, iklim kelas hingga akan lebih efektif melalui program boarding school.

Tulisan ini bertujuan untuk mengetahui strategi pembentukan sikap disiplin warga negara muda melalui persekolahan. Adapun pokok bahasan yang akan di bahas dalam tulisan ini meliputi a) urgensi sikap disiplin; b) strategi pembentukan karakter disiplin melalui budaya sekolah; c) strategi pembentukan karakter disiplin melalui pengelolaan iklim kelas dan d) strategi pembentukan karakter disiplin melalaui efektifitas program boarding school.

\section{METODE PENELITIAN}

Tulisan ini menggunakan metode library research (kajian pustaka) dari berbagai tinjauan pustaka baik jurnal maupun buku yang menjadi bahan gagasan yang terkait dengan strategi strategi pembentukan sikap disiplin warga negara muda melalui persekolahan.

\section{HASIL \& PEMBAHASAN}

\section{Urgensi Sikap Disiplin}

Salah satu nilai yang dapat dikembangkan dalam pendidikan karakter ialah nilai disiplin yang diaktulisasikan dalam bentuk sikap nyata yang dapat di amati dan bersifat operasional. Hal ini juga diperkuat oleh program pemerintah melalui penguatan pendidikan karakter (PPK) yang telah berupaya mengamanatkan bahwa upaya penguatan pendidikan karakter haruslah ada kerjasama yang berkesinambungan antar berbagai komponen mulai dari keluarga, sekolah dan masyarakat (Kemendikbud, 2017: 5)

Hakikatnya pendidikan karakter berupaya menanamkan, menekankan dan mengaktualisasikan nilai-nilai karakter pada peserta didik. Tujuan pendidikan karakter ialah berupaya agar nilai yang telah ditanamkan lalu diterima peserta didik yang akan terwujud dalam perilaku secara sadar dalam kehidupan sehari-hari. Nilai-nilai yang ditanamkan tidak hanya diterima tetapi nilainilai yang tidak dibutuhkan siswa menjadi nilai yang dibutuhkan siswa melalui pembiasaan. Penanaman nilai-nilai karakter perlu diajarkan supaya mereka mampu menemukan nilai-nilai mereka sendiri sesuai dengan kebutuhan.

Salah satu faktor untuk menunjang pembelajaran yang efektif ialah sikap disiplin siswa. Hal ini dikarenakan tujuan utama dari disiplin ialah berupaya menwujudkan lingkungan pendidikan dan kesempatan untuk proses pembelajaran yang efektif. Tujuan disiplin dalam persekolahan menurut Rachman (2003: 83) secara umum ada dua yang meliputi: 1) membantu terbentuknya perilaku yang mampu membantu siswa agar menentukan perilaku yang benar dan salah dan 2) mengupayakan pembiasaan peserta didik melalui aturan-aturan yang diberlakukan agar mampu memahami diri yang ada lingkungan sekolah.

Menurut Ghorbani, et. al (2013: 305314) mengemukakan bahwa salah satu alat 
untuk mewujudkan tujuan pendidikan ialah melalui proses pembelajaran yang pada akhirnya mengarah pada pertumbuhan siswa dan kemajuan dalam setiap dimensi. Pendapat di atas lebih terfokus pada nilai agar seseorang taat dan patuh saja. Satu sisi lain juga membahas bahwa disiplin tidak hanya sikap patuh terhadap aturan tetapi juga dipahami sebagai penempatan diri secara sadar untuk berbuat sesuai dengan keyakinannya. Makna patuh disini diartikan siswa boleh melanggar ketaatan dan kepatuhan apabila tidak sesuai dengan hati nuraninya dan bersifat tidak memberikan penjelasan terhadap efek yang diberikan jika mematuhi aturan yang diberikan (Grant, 1997: 101).

Uraian mengenai disiplin pada dasarnya haruslah diupayakan di bentuk secara sadar agar peserta didik mampu untuk patuh melalui pembiasaan yang ada dan berlaku terutama di sekolah. Upaya membentuk sikap disiplin dipengaruhi oleh dua faktor yaitu internal dan eksternal (Unaradjan, 2003: 24). Faktor yang akan dibahas dalam tulisan ini ialah faktor eksternal melalui persekolahan. Persekolahan menjadi salah satu faktor yang memberikan kontribusi lebih dalam upaya pembentukan sikap disiplin. Pembentukan sikap disiplin dapat dilakukan melalui persekolahan dibedakan dalam tiga bentuk strategi disiplin meliputi 1) strategi sensitif yang memberikan efek positif dalam membentuk sikap dan perilaku; 2) strategi direktif lebih menekankan pada upaya pemberian motivasi dan hukuman secara langsung; dan 3) strategi agresif lebih pada pemberian penguatan negatif dengan sanksi yang diberikan (Roache dan Lewis 2011: 237; de Jong, Romi., et. al, 2013: 585).

Berdasarkan pendapat di atas maka jelas bahwa pembentukan sikap disiplin peserta didik dapat melalui berbagai faktor salah satunya melalui persekolahan dengan mengupayakan berbagai strategi yang harus dibentuk mulai dari budaya sekolah, iklim kelas dan program boarding school.

\section{Strategi Pembentukan Sikap Disiplin Melalui Budaya Sekolah}

Budaya sekolah setiap sekolah memiliki ciri khas dan keunikan masingmasing. Hal ini dikarenakan budaya sekolah tersebut dibentuk oleh sekelompok orang yang berinteraksi antarwarga sekolah baik guru, siswa, orang tua, masyarakat bahkan warga sekolah yang berada dalam lingkungan sekolah yang membentuk kebiasaan yang menjadi tradisi di lembaga tersebut. Menurut Wiyani, (2013: 99) dan Hongboontri C, Keawkhong N (2014: 3) bahwa hakikatnya pembahasan budaya sekolah sangat luas tidak hanya terfokus pada aspek lingkungan tetapi juga berbagai aspek lain mulai dari kegiatan ritual yang menjadi rutinitas di sekolah, hubungan antar komponen dalam sosio kultural maupun kegiatan tambahan ekstrakurikuler dan intrakurikuller serta proses kebijakan yang di ambil untuk membentuk keputusan yang berlaku di sekolah tersebut.

Hal ini juga diperkuat oleh Sukadari dkk (2015: 60) bahwa budaya sekolah ialah hasil kesepakatan bersama antarwarga sekolah yang terdiri dari seperangkat nilai, adat, norma, tradisi dan kebiasaan yang bersifat baik maupun tidak baik yang berkembang secara turun menurun.

Budaya sekolah dalam keterkaitan dengan sikap disiplin merupakan salah satu aspek yang berpengaruh. Hal ini dikarenakan hubungan yang terdapat dalam budaya sekolah lebih menekankan pada hubungan antar peserta didik dengan pendidik, pendidik dengan pendidik dan antara anggota kelompok masyarakat dengan warga sekolah (Hojjat, 2015: 6).

Strategi melalui budaya sekolah yang terbentuk akan memberikan pengaruh terhadap sesuatu yang akan dibentuk dan dikembangkan dengan pelibatan seseorang dalam lingkungan tersebut. Pengaruh tersebut mampu memberikan dampak yang baik ataupun buruk bagi warga sekolah yang ada dalam lingkungan tersebut.

Upaya pembentukan sikap disiplin dapat dilakukan melalui pembiasaan yang dilaksanakan oleh warga sekolah dalam budaya sekolah. Adanya efektifitas mengenai pentingnya pembiasaan melalui budaya sekolah juga dikemukakan oleh Craig, (2009: 13), Hongboontri \& Chaokongjakra, (2011: 3), Jurasaite-Harbinson \& Rex, (2010: 289), Kleinsasser, (2013: 87), Muhammad, (2009: 3) dan Schien, (2010: 6) bahwa adanya kerjasama secara kolaboratif dan berkesinambungan dari berbagai pihak yang ada di sekolah untuk membangun dan mengembangkan budaya sekolah positif sesuai dengan tujuan sekolah tersebut. Budaya sekolah tersebut tidak dapat terhindar dari nilai-nilai kepercayaan dan pembiasaan yang dilakukan oleh warga sekolah dalam membentuk budaya sekolah berbasis nilai karakter. 
Uraian di atas jelas bahwa pengembangan budaya sekolah atau kultur sekolah penting dilaksanakan dengan tujuan membantu meningkatkan mutu pendidikan terutama dalam membantu mengembangkan pembentukan karakter siswa. Pengembangan budaya sekolah berbasis nilai dan karakter akan sangat membantu pendidik dan peserta didik serta tenaga kependidikan menjadi warga sekolah yang berkarakter (Hall, G., \& Hord, 2015: 35)

Pengembangan perubahan budaya sekolah perlu dilakukan untuk merespon kondisi pendidikan saat ini yang belum mampu secara optimal membentuk karakter yang diharapkan. Pemberian perhatian lebih oleh kepala sekolah dan guru dalam manajemen iklim budaya sekolah memberikan dampak yang baik dalam rangka pelaksanaan pendidikan karakter di sekolah.

Menurut Wiyani (2013: 141) ada beberapa upaya pengembangan diri yang dapat dilakukan melalui pembiasaan budaya sekolah meliputi:

1) Pembiasaan keteladanan

Pembiasaan keteladanan dalam hal ini ialah perilaku yang tidak terprogram yang ditunjukkan oleh perilaku guru, kepala sekolah ataupun peserta didik yang perilakunya dapat dijadikan panutan oleh warga sekolah. Akan tetapi pembiasaan paling efektif jika dilaksanakan oleh guru dan kepala sekolah terhadap peserta didik dengan memberikan contoh tindakan positif. Guru dalam hal ini sebagai teladan dalam membentuk sikap disiplin harus menunjukkan perilaku disiplin. Pendapat di atas juga didukung oleh Rickwood, G (2013: 7) bahwa kebiasaan guru dan warga sekolah yang datang tepat waktu dalam kegiatan sekolah akan memberikan pengaruh yang signifikan terhadap kebiasaan siswa dalam disiplin waktu. Siswa akan menjadikan guru sebagai teladan ataupun panutan bagi siswa dalam mencontoh perilaku. Pembiasaan melalui keteladanan tersebut terbentuk secara alami dalam budaya sekolah sebagai komponen utama.

2) Pembiasaan spontan

Pembiasaan yang dimaksud dalam hal ini ialah melalui kegiatan yang tidak terjadwal akan tetapi terjadi secara spontan mulai dari pembiasaan senyum, sapa, pemberian salam sebelum memulai pembelajaran di kelas, membuang sampah pada tempatnya, budaya antri, kunjungan rumah yang sedang sakit, saling mengingatkan ketika melanggar tata tertib di sekolah serta menunjukkan sikap setia kawan antarteman. Uraian di atas ialah pembiasaan spontan secara umum untuk membentuk budaya sekolah yang positif.

Secara khusus upaya pembentukan sikap disiplin melalui pembiasaan spontan ini dapat dilakukan mulai dari guru memperingatkan siswa jika terlambat sekolah, pemberian sanksi kepada peserta didik dan guru jika masih melanggar tata tertib sekolah.

3) Pembiasaan rutin

Pembiasaan yang dimaksud ialah kegiatan-kegiatan pembentukan karakter tersebut terintegrasi di dalam kegiatan rutin siswa sehari-hari di sekolah mulai dari upacara bendera setiap hari senin, pembiasaan doa bersama setiap memulai dan mengakhiri pembelajaran di kelas, pengecekan kerapian dan kebersihan berkala, kegiatan kebugaran setiap minggu dan pemeliharaan kebersihan (jumat bersih). Kegiatan tersebut secara umum dikembangkan di dalam budaya sekolah.

Pembiasaan rutin secara khusus dalam membentuk sikap disiplin dapat dilakukan melalui adanya rekapitulasi pecatatan kehadiran peserta didik, pembuatan jadwal kesegaran seminggu sekali, penetapan waktu mulai dan akhir pembelajaran sesuai dengan waktu, pemberian sanksi tegas dan adanya jadwal pembagian piket kelas.

4) Pengkondisian

Pembiasaan ini merupakan faktor pendukung dalam pembentukan karakter seperti kebersihan toilet siswa, pelestarian lingkungan di sekitar dan artefak melalui katakata bijak yang menjadi pajangan di lorong sekolah.

Uraian mengenai pembiasaan yang dilakukan mulai dari keteladanan, rutin, spontan dan pengkondisian mampu mengembangkan budaya sekolah yang positif dalam upaya pembentukan karakter warga negara.

Memperkuat pendapat di atas Mansyur (2011: 11) bahwa ada beberapa pengembangan diri dalam upaya pembentukan karakter melalui budaya sekolah meliputi a) kegiatan rutin, kegiatan yang dilakukan siswa secara terus menerus dan konsisten setiap saat di sekolah; b) kegiatan spontan, peserta didik melakukan secara spontan pada suatu kondisi tertentu, misalnya ketika ada teman yang terkena musibah maka akan mengumpulkan sumbangan; c) keteladanan, perilaku dari guru, tenaga kependidikan, kepala sekolah, dan peserta didik dalam memberikan contoh melalui tindakan yang baik sehingga menjadi tauladan atau panutan bagi peserta didik lain; d) 
pengkondisian, penciptaan kondisi yang menjadi pendukung terlaksananya pendidikan karakter di sekolah, misalnya kebersihan lingkungan halaman. Penggalakan penanaman pohon, tempat buang sampah, toilet yang bersih, poster kata-kata bijak sebagai pengkondisian di dalam kelas dan di sekolah.

$$
\text { Pembentukan Budaya sekolah }
$$

berbasis karakter memberikan pengaruh yang signifikan dalam membentuk sikap disiplin siswa. Hal ini sejalan dengan hasil penelitian Gage, et. al (2016: 513) bahwa ada beberapa upaya yang dapat dilakukan untuk membentuk sikap disiplin siswa salah satunya melalui pengembangan budaya seperti 1) penanaman nilai-nilai moral yang dilaksanakan bersama orang tua siswa; 2) menciptakan hubungan yang positif antara guru dan siswa dalam pembelajaran; dan 3) pengembangan budaya sekolah melalui keteladanan dan pengkondisian terhadap siswa yang indisipliner.

Sejalan pendapat di atas hasil penelitian De Wit, et. al (2000) bahwa adanya pembiasaan guru dan warga sekolah untuk membentuk karakter disiplin dengan datang tepat waktu selain itu juga pembentukan karakter disiplin dapat dilaksanakan melalui keteladanan guru. Pembiasaan yang dilaksanakan tersebut akan memberikan pengaruh yang signifikan terhadap kebiasaan siswa dalam disiplin waktu. Pembiasaan melalui keteladanan tersebut terbentuk secara alami dalam budaya sekolah sebagai komponen utama karena guru merupakan panutan dan contoh bagi siswa terutama di sekolah.

Uraian mengenai keberhasilan budaya sekolah terhadap pembentukan sikap disiplin menunjukkan bahwa melalui peningkatan budaya sekolah yang positif maka akan memberikan dampak yang positif pula dalam meningkatkan hasil akademik, sosial dan perilaku positif bagi semua siswa. Oleh karena itu pembiasaan yang dapat dilakukan dalam upaya pembentukan karakter disiplin melalui pembiasaan keteladanan guru, pembiasaan guru, pembiasaan rutin dan pengkondisian.

\section{Strategi Pembentukan Sikap Disiplin Melalui Pengelolaan Iklim Kelas}

Strategi pembentukan sikap disiplin yang kedua ialah iklim kelas. Iklim kelas menjadi salah satu unsur pembentuk sikap disiplin siswa. Oleh karena itu pentingnya kemampuan guru untuk membentuk dan mengelolah iklim kelas yang kondusif. Secara umum ciri iklim kelas ialah suasana kelas yang terbentuk karena adanya pola interaksi atau komunikasi antar guru dan siswa atau siswa dengan siswa.

Nasution (2005: 119-120) mengemukakan bahwa terdapat tiga jenis suasana kelas yang akan terbentuk selama pembelajaran di kelas yang akan dihadapi siswa. Ketiga suasana tersebut meliputi 1) suasana kelas yang bersifat otoriter. Dalam suasana ini guru menjadi pemilik kekuasaan mutlak yang mendominasi secara penuh dan memaksa untuk mencapai tujuan yang diharapkan tanpa memahami kondisi dan kebutuhan siswa. Kelemahan tipe ini ialah siswa akan melaksanakan segala perbuatan dan keberhasilan dnegan secara terpaksa sehingga siswa mengalami kondisi menanggung beban; 2) suasana kelas bersifat permisif yang berarti guru terlalu memberikan keluwesan dan kebebasan pada siswa sehingga guru tidak memberikan kontrol terhadap siswa. Suasana tipe ini baik bagi beberapa karakteristik siswa tetapi juga tidak baik bagi siswa yang tingkat mawas dirinya rendah untuk mengembangkan diri. Kelebihan dari tipe ini ialah siswa tidak merasa tertekan, frustasi dan merasa terpaksa dalam pembelajaran di kelas. Idealnya dalam tipe ini guru harus mengetahui posisi sebagai fasilitator pembelajaran.

Dan 3) Suasana kelas tipe demokratis atau "rill" yang ditandai adanya kebebasan pada siswa tetapi tetap ada pengendalian dari guru di kelas. Guru dalam tipe sebagai pemegang kontrol karena siswa akan berkembang sesuai kompetensi tanpa paksaan.

Uraian mengenai ketiga tipe suasana kelas jelas telah tergambar bahwa pengelolaan iklim kelas yang tepat akan sangat memberikan pengaruh terhadap pembentukan karakter siswa.

Upaya mencapai iklim kelas yang kondusif maka harus adanya kemampuan pengelolaan iklim kelas yang tepat. Pengelolaan yang dapat dilakukan mulai dari membentuk lingkungan belajar dan hubungan interaksi antar warga kelas yang bertujuan untuk membentuk iklim kelas yang kondusif (Rubie-Davies, 2015: 112; Rubie-Davies, 2016: 445).

Ketepatan pengelolaan kelas yang dilaksanakan oleh guru dan peserta didik akan mampu membentuk motivasi dan hasil akademik siswa yang baik sehingga upaya pembentukan sikap disiplin siswapun akan 
lebih efektif karena iklim kelas yang terbentuk telah mendukung.

Hal ini menunjukkan bahwa untuk mencapai keberhasilan siswa maka pengelolaan iklim kelas haruslah mendukung pencapaian tujuan pembentukan karakter yang diharapkan. Hasil penelitian Altaf (2015: 27) mengemukakan bahwa salah satu faktor penting dalam upaya membentuk perilaku sosial-ekonomi dan motivasi belajar siswa ialah pengelolaan iklim kelas yang meliputi: a) Hubungan Interpersonal (keterlibatan, afiliasi, dan dukungan); b) tujuan orientasi (tugas orientasi dan kompetisi); dan c) Pemeliharaan Sistem dan Perubahan (ketertiban dan organisasi, aturan kejelasan, kontrol guru, dan inovasi).

Keberhasilan dalam pengelolaan iklim kelas ditunjukkan dengan adanya peningkatan motivasi, hasil akademik dan mempermudah untuk mencapai tujuan pembentukan sikap disiplin siswa karena siswa akan merasa nyaman sehingga melaksanakan aturan yang ada secara sadar tanpa ada paksaan.

Pentingnya pengelolaan kelas yang tepat untuk membentuk sikap disiplin juga dikemukakan oleh Osher (2010) yang bahwa terdapat tiga pendekatan yang menjanjikan untuk meningkatkan praktik disiplin sekolah dan perilaku siswa ialah pendekatan ekologi untuk pengelolaan kelas; seluruh sekolah mendukung perilaku positif; dan pengembangan remaja positif. Ketiga pendekatan tersebut dapat dilaksanakan secara bersamaan.

Uraian di atas jelas bahwa pengelolaan iklim kelas yang baik akan memberikan pengaruh terhadap pembentukan sikap disiplin siswa. Iklim kelas yang kondusif akan membantu siswa lebih mudah untuk melaksanakan semua peraturan yang ada secara sadar tanpa paksaaan.

\section{Strategi Pembentukan Sikap Disiplin Melalui Program Boarding School}

Pembentukan karakter disiplin akan lebih efektif jika diwujudkan dalam pendidikan yang terintegrasi melalui tri pusat pendidikan mulai dari keluarga, sekolah dan masyarakat (Hayah, 2016: 2; Darmawan, 2015: 18).

Sistem persekolahan berbasis boarding school merupakan salah satu perwujudan dari pendidikan terintegrasi. Sistem boarding school merupakan salah satu alternatif untuk mampu mengatasi kesenjangan antara ketiga fungsi tri pusat pendidikan. Adanya keterbatasan dari tri pusat pendidikan menyebabkan timbulnya permasalahan moralitas bangsa sehingga adanya sistem pendidikan yang melibatkan peran tri pusat pendidikan harusnya mampu meminimalisrkan hal-hal yang bertentangan dengan nilai-nilai yang harusnya dikembangkan.

Salah satu pertimbangan dalam pemilihan boarding school ialah tingkat keberhasilan dalam pembentukan karakter siswa. Orang tua mengakui dengan adanya program ini membuat perubahan perilaku yang mengarah pada kemampuan membangun kedisiplinan dan mengembangkan kemandirian. Dengan adanya sistem boarding school menjadikan siswa mampu melakukan interaksi dan beradaptasi sebagai pribadi maupun masyarakat dalam lingkup kecil (Schaverien 2011: 138-155). Hal ini juga diperkuat oleh Martin \& Ginns (2011: 10-11) bahwa sistem asrama atau boarding di era saat ini menjadi kebutuhan penting di berbagai negara. Salah satu negara yang mewajibkan sekolah berbasis asrama ialah Australia. Hal ini dikarenakan peran asrama dan program yang ada juga dituntut untuk berkembang sesuai tuntutan zaman salah satunya ialah perkembangan karakter taat hukum dan kemandirian yang menjadi tujuan utama sistem asrama. Hakikatnya tujuan dari adanya sistem asrama ialah melalui asrama mampu menyediakan lingkungan yang aman aman, positif belajar di mana remaja dapat mengembangkan tidak hanya dalam kapasitas fisik dan akademis tetapi sama pentingnya sosial, emosional dan spiritual.

Pendidikan karakter melalui sistem boarding school pada dasarnya bertujuan untuk membentuk manusia tangguh, memiliki moral yang baik, mulia, toleransi, mampu berkembang dinamis, patriotik, berorientasi pada ilmu pengetahuan dan teknologi, yang semuanya dijiwai oleh iman dan berkomitmen kepada Tuhan berdasarkan Pancasila.

Keberhasilan pendidikan terintegrasi juga dikemukakan oleh Shane, Erik, et. al (2008: 197) bahwa integrasi tri pusat pendidikan mampu membentuk dan mengembangkan nilai-nilai dengan motivasi yang tinggi, memilki sikap disiplin dan tanggung jawab. Hal ini dikarenakan sistem sekolah asrama bertujuan membentuk peserta didik mampu menjadi bagian dari masyarakat dengan pembiasaan yang dilakukan melalui indoktrinasi nilai dan promosi kebudayaan. Nilai-nilai yang dikembangkan menjadi nilai 
dasar dan karakter bagi siswa untuk kepentingan saat ini dan akan datang.

Sistem pendidikan berbasis boarding school memiliki kelebihan yang tidak bisa didapatkan di sekolah umum biasanya dari berbagai aspek salah satunya adanya fasilitas yang lebih lengkap. Kelebihan yang ditawarkan tersebut mengingat bahwa sistem pendidikan ini berupaya mampu mengintegrasikan tiga sistem pendidikan mulai dari keluarga, sekolah dan masyarakat. Kelebihan-kelebihan sekolah model ini juga bisa dilihat pada beberapa aspek (1) siswa dalam kelas tidak lebih banyak dibanding sekolah umum biasanya sehingga keaktifan dan pengawasan guru terhadap siswa lebih mudah; (2) memprioritaskan mutu pendidikan dan soft skills untuk siswa sehingga lebih terarah di bandingkan sekolah umum; (3) mengutamakan fasilitas yang lengkap seperti perpustakaan, ruang teater, fasilitas olahraga, keahlian dalam menguasai muatan lokal yang sesuai kompetensi; (4) sekolah sistem ini mengedapankan standar akademik yang berstandar tinggi sehingga mampu bersaing dan menjadi acuan siswa untuk manjawab tantangan global; (5) sistem boarding memberikan alternatif pilihan mata pelajaran yang diampuh dan ketrampilan diri untuk mengasah kompetensi siswa; (6) sekolah ini melibatkan profesional dalam membuat program dan kebijakan yang akan dikembangkan (Maksudin, 2013: 106-107). Memperkuat pendapat di atas juga dikemukan oleh Westhuizen, et. al (2008: 205-225) bahwa salah satu faktor terbentuknya dikap disiplin selain dari budaya organisasi yang dibangun dengan baik tetapi juga melalui pengawasan di asrama.

Berdasarkan uraian tersebut jelas bahwa ada beberapa kelebihan dibanding sekolah umum. Kelebihan tersebut menunjukkan bahwa sistem pendidikan ini lebih berorientasi pada pembentukan nilai melalui fasilitas fisik maupun non fisik yang telah disediakan oleh sekolah. Salah satu kelebihan dari nilai yang dikembangkan ialah mampu membentuk sikap disiplin siswa. Program-program yang ada pada sekolah berbasis boarding akan memberikan pengaruh yang besar dalam upaya pembnetukan sikap disiplin siswa. Program yang dibentuk baik berupa aturan tata tertib, kegiatan utama asrama dan kegiatan tambahan asrama. Semua kegiatan yang dilaksanakan akan mendukung terwujudnya sikap disiplin siswa yang ada.

\section{KESIMPULAN}

Pembentukan sikap disiplin menjadi salah satu aktualisasi karakter personal warga negara yang harus dibentuk oleh berbagai pihak salah satunya ialah melalui persekolahan. Sikap disiplin penting untuk dibentuk pada warag negara dikarenakan beberapa hasil penenlitian menunjukkan bahwa salah satu indikator menggambarkan kualitas pendidikan suatu negara ialah sikap disiplin. Selain itu rendahnya sikap disiplin merupakan salah satu penyebab seseorang melakukan hal-hal yang bertentangan dengan nilai-nilai yang harusnya dilaksanakan.

Sikap disiplin merupakan sikap yang menunjukkan perilaku patuh dan taat terhadap peraturan yang ada secara sadar tanpa ada paksaan yang bersifat melekat dan menjadi kebiasaan. Pembentukan sikap disiplin warga negara dapat dilakukan melalui persekolahan mulai dari 1) pembentukan sikap disiplin melalui pengembangan budaya sekolah dengan melakukan pembiasaan keteladanan, pembiasaan spontan, pembiasaan rutin dan pengkondisian; 2) pembentukan sikap disiplin melalui pengelolaaan iklim kelas yang kondusif sehingga upaya membentuk sikap disiplin siswa akan lebih mudah jika guru dan siswa secara berkolaboratif membangung iklim kelas yang baik dan 3) pembentukan sikap disiplin melalui program boarding school. Salah satu kelebihan sekolah berbasis boarding ialah adanya pengintegrasian peran tri pusat pendidikan mulai dari keluarga, sekolah dan masyarakat. Pembentukan sikap disiplin akan lebih mudah terwujud jika siswa berada pada sekolah berbasis boarding. Beberapa program dalam sistem ini sangat efektif untuk membentuk sikap disiplin siswa mulai dari program yang dibentuk baik berupa aturan tata tertib, kegiatan utama asrama dan kegiatan tambahan asrama. Semua kegiatan yang dilaksanakan akan mendukung terwujudnya sikap disiplin siswa yang ada.

\section{DAFTAR PUSTAKA}

Altaf, M. (2015). Exploring classroom environment through perception. An overview of various inventories. International Journal of Novel Research in Education and Learning, 2, pp: 23-32

Craig, C. J. (2009). Research in the midst of organized school reform: Versions of teacher community in tension. 
American Educational Research Journal, 46(2), pp: 598-619.

Darmawan, Hendra. (2015). A model of character education as reflected in fuady's the land of five towers. International Journal on Studies in English Language and Literature (IJSELL. 3(8). Pp:16-22. ISSN 23473126 (Print) \& ISSN 2347-3134 (Online)

De Jong, Romi, Jan van Tartwijk, Theo Wubbels, Ietje Veldman \& Nico Verloop (2013). Student teachers' discipline strategies: relations with self-images, anticipated student responses and control orientation, Educational Studies, 39 (5), pp: 582597

De Wit, D. J., Offord, D. R., Sanford, M., Rye, B. J., Shain, M., \& Wright, R. (2000). The effect of school culture on adolescent behavioral problems: selfesteem, attachment to learning, and peer approval of deviance as mediating mechanisms. Canadian Journal of Sport Psychology, 16, pp: 15-38

Fathurahman, Pupuh. (2012) "Model of the character education in developing countries" Journal of Applied Sciences Research, 8(3), pp: 18131816

Gage, Nicholas A. (2016). Student perceptions of school culture as predictors of office discipline referrals. American Educational Research Journal. 53(3), pp: 492-515

Ghorbani, Somayeh, et al (2013). Investigating the effect of positive discipline on the learning process and its achieving strategies with focusing on the students' abilities. International Journal of Academic Research in Business and Social Sciences. 3(5), pp: 305-314

Grant, Barbara. (1997). Disciplining students: the construction of student subjectivities. British journal of sociology of education 18(1), pp: 101114

Hall, G., \& Hord, S. (2015). Implementing change patterns, principles, and potholes ( $4^{\text {th }}$ ed.). Upper Saddle River, NJ: Person Education.

Harian Jurnal Asia, diakses 1 Januari 2017, pukul. 1046 WIB dari https://www. Jurnalasia.com/opini/pengaruh-gadgetdi-kalangan-pelajar/.
Hayah. (2016). Character education in islamic boarding school and the implication to students' attitude and critical thinking skills on biodiversity learning. Journal of Physics. 1(7). pp: 1-16 Doi:10.1088/1742-6596/755/1/011001

Hojjat, Mahmoudi. H, Brown R., Saribagloo A, et. al. (2015). The role of school and basic psychological Nedds on Iranian Adolescents Academic Alienation: A Multi-Level Examination. Youth and society, pp: 1-21

Hongboontri, C., \& Keawkhong, N. (2014). School Culture: Teachers' Beliefs, Behaviors, and Instructional Practices. Australian Journal of Teacher Education, 39(5), pp: 1-12

Jurasaite-Harbinson, E. \& Rex, L. A. (2010). School cultures as contexts for informal teacher learning. Teaching and Teacher Education, 26(1), pp: 267-277

Kementerian Pendidikan dan Kebudayaan (2017). Pedoman penguatan karakter. Jakarta: Kemendikbud.

Kleinasser, R. C. (2013). Language teachers: research and studies in language(s) education, teaching, and learning in Teaching and Teacher Education, 19852012. Teaching and Teacher Education, 29, pp: 86-96

Maksudin, (2013). Pendidikan karakter nonDikotomik. Yogyakarta: Pustaka Pelajar

Mansyur dkk. (2011). Pedoman pelaksanaan pendidikan karakter (Berdasarkan pengalaman Satuan Pendidikan Rintisan). Jakarta: Kementrian Pendidikan Nasional Badan Penelitian dan Pengembangan Pusat Kurikulum dan Perbukuan.

Martin j. Andrew, Ginss, paul, Liem, D. Arief Gregory. (2014). Boarding school, academic motivation and engagement, and psychological well-being: large scale investigation. American educational research journal. 51(5), pp 1007-1049

Muhammad, A. (2009). Transforming school culture: how to overcome staff division. Blommington, IN: Solution Tree Press.

Nasution, (2005). Berbagai pendekatan dalam proses belajar dan mengajar. Jakarta: PT Bumi Aksara.

Osher, et. al (2010) How can we improve school discipline?" Educational Researcher, 39(1), pp: 48-58 
Rachman, Maman. (2008). Manajemen kelas, Jakarta: Depdiknas

Rickwood Greg (2013). School culture and physical activity: A systematic review. Journal of Educational Administration and Policy. 1 (43), pp: 1-21

Roache, J. E., and R. Lewis. (2011). "The carrot, the stick, or the relationship: what are the effective disciplinary strategies?" European Journal of Teacher Education 34, pp: 233-248

Rubie, Davies., Asil, Mustafa., Teo, Timothy. (2016). Assessing measurement invariance of the student personal perception of classroom climate across different ethnic groups. Journal of Psychoeducational Assesment. 34 (5), pp: 442-460

Rubie-Davies, C. M. (2015). Becoming a high expectation teacher: Raising the bar. London, England: Routledge

Schein, E. H. (2010). Organizational culture and leadership (4th ed.). San Francisco, CA: Jossey Bass.

Shane, Erik,. et. al. (2008). Military boarding school perspectives of parental choice: a qualitative inquiry. Journal of School Choice: International Research and Reform. 2(2), pp: 178-198

Sjarkawi. (2011). Pembentukan kepribadian anak: peran moral, intelektual, emosional dan sosial sebagai wujud integritas membangun jati diri. Jakarta: Bumi Aksara

Sukadari, Suyata dan Shodiq A. Kuntoro. (2015). Penelitian etnografi tentang budaya sekolah dalam pendidikan karakter di sekolah dasar. Jurnal pembangunan pendiidkan. 3(1), pp: 59-68

Tribun News Aceh, diakses 15 Januari 2017, pukul. 14.00 WIB dari https://www. Google.co.id/amp/aceh.tribunnews.co $\mathrm{m} / \mathrm{amp} / 2013 / 01 / 03 /$ potret-burampendidikan-kita.

Unaradjan, Dolet, 2003. Manajemen disiplin. Jakarta: PT Gramedia.

Westhuizen, Philip C., Oousthuizen, I., Wolhuter,. C. (2008). The relationship between an effective organizational culture and student discipline in a boarding school. Education and urabn society. 4(2), pp: 205-225

Wiyani, Novan , Ardy. (2010). Prosedur penelitian suatu pendekatan praktik. Jakarta: Rineka Cipta. 